\title{
The Tragic Spirit of Shostakovich's Vocal Cycle
}

\author{
Mizhong $\operatorname{Lin}^{1}$ \\ ${ }^{1}$ College of Music, Southwest University, Chongqing, China \\ Correspondence: Mizhong Lin, College of Music, Southwest University, Chongqing, China. Tel: \\ 86-138-8339-9123. E-mail: 56204449@qq.com
}

Received: July 15, 2015 Accepted: August 21, 2015 Online Published: August 26, 2015

doi:10.5539/ass.v11n22p10 URL: http://dx.doi.org/10.5539/ass.v11n22p10

\begin{abstract}
Tragedy is an important aesthetic form. And the tragic spirit is a sense of tragedy reflected by both the artist and the artistic work. On the one hand, the tragedy spirit of Shostakovich's vocal cycle comes from the aesthetic preference of the Russian nation, traditional art and the unfortunate fate of the composer himself, and on the other, it is also expressed via the description of death, pessimistic love and the suffering of life. The various composing techniques are the most reliable communication tool for the tragedy spirit of vocal cycle.
\end{abstract}

Keywords: Shostakovich, vocal cycle, tragedy

\section{Tragedy and the Spirit of Tragedy}

Tragedy is not just a tragic event occurred in life or a drama in parochial theory of literature, it is a kind of beauty in the form of aesthetic categories as well. It not only belongs to the drama category, but also aesthetic category; not only to the category of literature and art, but also to the philosophical category. Aristotle established the tragic theory which became the source of the western tragedy tradition. He defined it as the "imitation of a complete and whole action having a proper magnitude" $\left(1541^{\mathrm{a}}\right)$ (Aristotle, 1981). Aristotle believed that it is the hero (i.e., good people who have committed mistakes) himself who leads to the tragedy rather than the fate or behaviour of his character. And, according to his deduction, tragedy has a purifying effect, including a pain, non-accidental "harmless pleasure" (as Rung had called it) (Rung, 1987). Then estheticians and philosophers such as Custer Salvi Castro, Corneille, Lessing, Schiller, Hegel, Schopenhauer, Nietzsche developed and evolved the theories of tragedy around the concept of tragedy and "Purification" (catharsis, $1449^{b}$ ) and other theories of tragedy. Belinsky who rooted in the soil of the Russian philosopher thinks that the object of tragedy should come from complicated life. However, Chernyshevsky argued that "tragedy is terrible things in life," (Chernychevsky, 1958) and Engels revealed the essence of tragedy as "the inevitable requirement of history, and this requirement is actually impossible" (Engels, 1966). Engels' theory has got broad and deep recognition in Russia, especially in the period of the Soviet regime.

The so-called tragic spirit, is a kind of tragic feelings embodied in both the artist himself and his artistic work and it is also known as "tragic vision" or "sense of tragedy". "It is an important topic in modern western aesthetics of tragedy. It's not only a world outlook but also an artistic view; it is reflected not only in the tragedy of the artist but also reflected in the tragic protagonists. " (Cheng, 1992). The world outlook is related to the corresponding artist and the artistic view to artistic taste. I would like to argue in this thesis, which will also apply to any field of art, including music. Music of the tragic spirit is reflected in the Shostakovich's personality, psychology and writing habits, meanwhile, is expressed by non-visual, non-semantic ways. Yet it is precisely because the non-visual and non-semantic music, we get a broader and more flexible imagination to the tragic heroes of music compositions, and get shocked by stronger tragic feelings.

\section{The Tragedy Tradition and the Tragic Life: The Existential Foundation of Shostakovich's Tragic Spirit}

As mentioned above, the tragic spirit embodied in the works of art, is also reflected in the artist himself. Shostakovich's vocal cycle tragic spirit, his nation, the times and personal experience are closely linked. Three aspects of Russian national aesthetic tradition, Russian intellectuals, tradition and existing foundation of Shostakovich's personal life experiences are the spokesman for this link.

To understand the aesthetic idea of the artist, it is necessary first to explore from the nation and the social perspectives. To comment upon a piece of tragic art, it is a must to put the tragic poet or dramatist and his work into the concrete historical environment, and apply them to the historical background of the contemporary 
period, otherwise it would be very hard to find the true causes of how the piece of work of art produced or shaped. Shostakovich's spirit of tragedy aesthetic first roots from the Russia national history of suffering and thus the preference caused hence.

Berdyaev said that "Russian national history is one of the world's most painful histories" in his History of Russian Thought (Berdyaev, 1995). Only during such decades for the Nineteenth Century to the Beginning of the Twentieth Century, Russia has experienced the two world wars and the two domestic reforms. Every war and change happened at the cost of political turmoil and a large number of innocent civilians' death. No matter whether the political purpose of war is noble or not, it brings people death and disease and this is an undisputable fact. The painful life lets the Russian nation be brought a future always of cherished expectations and at the same time, inevitably returned a depression, and the national feelings of compassion. Russia's vast but sparsely populated territory to harsh environment, desert, swamp and the cold weather makes the Russians have all the time cherished a depressed, tragic aesthetic preferences, the religious belief in strong "compassion" complex deepened the Russians in the heavy historical accumulation of tragic consciousness and tragic "suffering culture" in the whole process of the development of art in Russia have shaped an unshakeable tradition. The historical, national tragedy of aesthetic preference is the basis for the existence of Shostakovich's tragic spirit.

The Russian intellectuals have unique spiritual features, and made it a fine tradition from generation to generation. The formation of this kind of inspired features is inseparable from Russia's unique geography, history, ethnic, religious, cultural and other related factors. Typical Russian intellectuals have strong patriotic feelings, but also have a strong critical spirit of patriotism based on emotion. However, no matter under what kind of systems, the Russian intelligentsia is always in an awkward position. On the one hand, they are not recognized as being considered as the mouthpiece of those in power and vain free riders, and on the other hand, they are always monitored and prevented by the authorities. The authorities even need their knowledge to serve the maintaining of production, living and ideology; they also worried that the critical awareness of the intellectuals will lead people to revolt against the authorities. Such a tradition lasted from Czarist times to the Stalin reign, "..... They hate their own intellectuals, this mainly stems from their social origins and socio-emotional......They hate gentle, civilized manners and intelligentsia......They still did not change their hostility to the entire culture (Berlin, 2010) ". The persecution of intellectuals never stops, it can be seen from the tragic fate of prominent intellectuals: Ryleyev was executed by hanging, the December Party poets were buried in Siberia or lost the will to fight there, Pushkin and Lermontov died in duels, Yesenin and Mayakovsky, Tsvetaeva committed suicide, Blok and Pasternak eventually died for being out of favour of the authorities.

The harsh living environment makes Russian intellectuals' creative writing a shade of tragedy: "The main characters of many artists' works were marginalized; they were closely linked to the social development trends and fate but not in cahoots, kept headstrong, inner conscience and sense of right and wrong when facing all kinds of social destruction, devastation and brutal elimination of many other similar kinds of violence (Berlin, 2010) ". While the tragic characteristics are represented as "in a certain period, temporarily overwhelming of the old forces which has great physical powers over the new forces, failures or setbacks with a certain historical inevitability, destruction of justice, the sacrifice of heroes, serious disaster, hardship, etc. (Yang, 2010) ". In this way the main characters of many artists' works were irreversible with a tragic fate: Catherine in Ostrovsky's Thunderstorm, Karenina in Leo Tolstoy's Anna Karenina, Lensky, Taki Onegin and Tatiana in Pushkin's Ye Eugen Onegin, Bashkir Marchi in Gogol's "Coat", and the Duke Ramesh in Dostoyevsky's "Idiot" and so on, are countless. The iron-fisted rule introduced from the reign of Tsar were clearly visible whether in politics or in the cultural battle lines, thought was bound, the humanity was devastated, intellectuals can only describe the hero's tragic fate as responses and echoes to real life. This creative writing tradition of tragedy provides suitable soil for Shostakovich's tragic spirit.

Any piece of work of tragic art is the personality self-disclosure of the tragic artist. Tragedies are always devoted to the artist's individual knowledge training, spiritual temperament, viewpoint and artistic talent. Of course, the most important thing is his own spiritual qualities of the tragic artist. That is something in the tragic artist's psychology. To understand the tragic spiritual of Shostakovich's music, one must understand his strongly tragic-coloured life.

Shostakovich is one of the most representative persons in the history of Russian music. He was known as a "Beethoven in twentieth Century". Some critics even believe that the music history in the 20th century of Soviet Union is just the composing history of Shostakovich. Although this point is to some degree somewhat over-exaggerated, his position as well as his influence is evident in history. 
Shostakovich was born in Russia's troubled times. Shostakovich witnessed the killings and bloody violence in his childhood. The tragic and dark scenes influenced his life, and established its gloomy music trait. At the age of 19, Shostakovich whipped up a storm in the world for his "first symphony", which won him a worldwide reputation. Then he created a lot of hot runner works, and received wide attention and recognition. He was considered to be a rising star. However, in 1936 an editorial "Chaos Instead of Music" on the Pravda had completely changed his life. Based on the novel of the same name Leskov's opera "Lady Macbeth of Mtsensk" was performed successfully in the Metropolitan Opera of New York, and broadcasted by London Radio Station BBC. The opera received overwhelming praise, in the Soviet Union, however, it suddenly suffered from "violent criticism of the government", Shostakovich himself was given twice attacks by the "Pravda" editorial within ten days. On the eve of the Soviet government of intellectuals "purge", the political climate was sensitive and depressive. In the meanwhile, a number of shostakovich's friends often inexplicably disappeared, and his sister was exiled. Such criticism was declared to be sentenced to death, so that shostakovich even came close to suicide. In several years shostakovich said in his memoirs: "on January $28,1936, \ldots$ I will never forget this day, because it is probably one of the most memorable days of my life. This article in Pravda third version has changed my life. It had no signature, just like an editorial, expressing his party's opinion. Actually it was Stalin's opinion, which was more important...Everyone avoided me. There was a phrase in the article, which says: 'all the results will be very bad'. So all of them waited for the bad results coming. Everyone thought that I had been finished, and the mood of waiting for the big moment has not left me (refer to arrest or execution). I had been labeled as the "enemies of the people", which meant that at the time what I didn't need to explain. Everyone should remember it. No matter in private or in public, 1 was under the title of the enemy of the people, a newspaper heralded my concert like this: today there is a public enemy Shostakovich's concert (Shostakovich, 1981) ". Due to the success of the fifth symphony and the outbreak of world war two, the Soviet government put more emphasis on the war, thus the strangulation that imposed on composers was slightly relieved. "Piano Quartet" written in 1940 has won the prize on behalf of the highest honor of Stalin. Though a flash in the pan, Cultural purges carried out in 1948, Shostakovich stood in the breach again who was charged with "formalism" and "the anti-people's art", finally lost his professorship. After Stalin's death, Shostakovich served as secretary of the Soviet union composers association and member of Defending world peace committee, which means that the composer officially recognized by government. Upon Shostakovich's death, he was highly evaluated by the authority, which called him the great composer of our time, the communist party's loyal fellow, an outstanding celebrity and politician, civil artist etc., and they thought that Shostakovich devote all his life to the development of Soviet music and rebuilding socialism humanitarian and ideal internationalism...

Shostakovich is a man of a mystery. Some suppose that he is a faithful public servant during the Soviet era, just as all official actions and public statements do. And others think that he lives in the gray area between the two extremes, just as many Soviet Union people do. Others regard him as a sympathetic artist, as well as a victim of tyranny. No one has his ups and downs as Shostakovich has ever had, and no one gets so many different comments as he does. However, there is no doubt that, as an artist who was named and shamed by officials for successive twice, and even deprived of his right to survive, his life is also a tragedy. He struggles in an oppressive political environment during his lifetime, and watches his close friends and colleagues die in a rolling wave of political movements. It takes Shostakovich on a roller coaster shuttling through the emotion of fear, worry, honor, praise and so on.

\section{The Tragic Fate of the Protagonists in the Tragic Works: The Construction of the Tragic Themes in Shostakovich's Vocal Cycle}

There is a high correlation between the theme and the lyric in a vocal music work. Although the poets, rather than the composers, write the lyrics, the composers have their say about the choice in lyrics in their works. From the choice in lyrics, Shostakovich prefers to use the poetry written by the poet or nation who has a tragedy fate. Pushkin, who lived under the rule of the Tsar seemingly gloriously but menially, finally died in a duel. Tsvetaeva, one of the most famous female poets in Russia's Silver Age, who was excluded and suppressed during the Great Purge, finally committed suicide against the authoritative brutality and for guarding her love, life and poetry. The lyric of "Jewish folk song" comes from the Jewish people's folk poetry. As the most ill-fated nation in the world, their folk poetry has their own inherent national characteristics. It is optimistic, while it is pessimistic as well. The choices in these poets' and nation's lyrics reflect Shostakovich's preference for tragic themes. These tragic themes include:

\subsection{Death}

The recreation of Shostakovich's music had the extremely profound influenced by Mahler. Shostakovich once said: "Mahler, a well-known Germancomposer, is not only my favorite composer but also a good example of the 
creation, whose ideal has changed on my creation, especially on the specific creative techniques and the topic of choice (Mi, 2008) ". Someone once said that "suffering and death" in tragedy can touch people's heart most, which makes big differences on Shostakovich. He has a special preference for the death theme like Mahler. The shadow of "death" can be seen everywhere in his works. Such as the symphonies No. 4, 7, 8, 13, 14, 15, etc. However, in the vocal music cycle, death is still one of composer's main themes, "before suicide" and "death" in the "Six Japanese Folks": the first song "Dead Boy" in "from Jewish folk poetry". The death has been involved in the first, the second, the third and the fifth in the "Michelangelo poetry suite" which is made up of six songs. From what mentioned above, the frequent appearance of death reflects the composer's tragic feelings in their deep soul.

\subsection{Love Elegy}

Love is one of the most beautiful and most moving emotions. However, love can bring endless pain and torment. Romance tragedy often showed in the Vocal Music Cycle of Shostakovich. The forth work "the first time and the last time" and the fifth work "hopeless love" in "Six Japanese Folks" reflect poets' memories of beautiful old days and despair after love died. The third work "Hamlet's soliloquy" in "Tsvetaeva's anthology" reflects Hamlet's sadness after his lover drowned, which greatly enhanced Hamlet's tragedy colours in his works.

\subsection{Complaints of Reality}

Some of Shostakovich's vocal cycles were created after 1960s. Shostakovich once became more cautious after experiencing twice "purge" and "criticism". Even he has to cover up and hide the inner feelings in the works by a variety of means. However, the loss of high-handed literature and art caused by Stalin's death let Shostakovich's late art could bump up the current politics and express dissatisfaction with the authorities' past violent behaviour through the mouth of a poet. In the last song of Michelangelo, he put the poet's feelings of anger into paper with almost straightforward language that there is full of "vain temptation and evil means in the shadow of my life". In the fourth song "Poet and Tsar" and fifth song "Don't Play the Drums" of Tvetayeva, Shostakovich implied the Soviet authorities persecuted artists through describing Nicholas I persecuted Pushkin and added honour after death. In the sixth song "To Akhmatova", Shostakovich also complained to and satirized the brutal Soviet authorities. While "that man who was hurt by your fatal fate and had turned immortality in his death bed" refers to Stalin himself.

\subsection{Sigh of Life and Description of the Suffering}

The hero in Shostakovich's vocal cycle is either an undiscovered and sighing poet--"My youth and death poems, no reading poems! Scattered in the dust bookstore nobody cares! As if one sad and helpless sigh" in the first song "My Poetry" of Tvetayeva, or civilians at the bottom of society and struggling between food and clothing. It is described that "Your father shackled in Siberia, and I languished in poverty.......My sorrow is darker than night" in the third song "Lullaby" of "Jewish poetry". In the sixth song "Abandoned Father", the father begged the daughter not to leave. In the seventh song "Songs of Poverty", only thatched roof, naked baby sleeping in the cradle......the spider web inside the knot, leaving me only the poor. In the ninth song "Winter", the sick child was lying on her side, the room is too cold, the wind was whistling outside......All of these is a true portrayal of the suffering life of the people.

\subsection{The Tragic Expression Under the Clear Coat}

There are still some bright and pleasant works in Shostakovich's vocal cycle occasionally. However, such work still implies a bitter expression under the clear coat. In the 11th song "Happiness"'" of "Jewish Folk Songs", the lyric describes a delighted woman who feels happy because her son finally becomes a doctor. The Jews suffered from discrimination and lose too much power and freedom in the anti-Semitic storm. In this environment, "Only the most competent Jewish university graduates could find a job, most of them were out of work (Berlin, 2010) ", so there is much to celebrate for Jews to get a job. On the background of the opposing Jews, the composer underscores the miserable life situation of Jews in the Soviet Union; Although the ninth work "Good times" sing the good life seemingly, the description of "Never flowers bloom for me, never dewdrops shine for me...I am the mistress of poor" implicated the composer's depress during the being criticized period-"I am singing a sad song, a non-word song deeply in my heart"; the fourth of "Michelangelo" described the joy of the aged to get love, even though, it still described the situation gloomily as "Tears are heavy as years, fallen more lonely than before...the way of night lead to desolation and storm, the boring sun went down slowly. The air are damp and bleak, darkness is climbing like shadow". The clear topic could not cover up the sad. 


\section{The Descriptive Technology of the Tragedy Spirit of Shostakovich's Vocal Music Cycle}

Although music has no semantic meaning or visually, but as the existence of mediation, the psychological mechanism synesthesia sets up a bridge between the musical sound and objects, so as to make music has the ability of performance. The key word "sad" of "Tragic" makes people associate words "desolation", "loneliness", "sigh" and "dolefulness", etc. The corresponding techniques are the slowness of speed, downside of melody, the repetition of unison and the reduction of dynamics. Shostakovich largely used these techniques in vocal music cycle to deeply reflect his works' tragic.

\subsection{The Long Line Progression of Downward Melody}

Through the using of aesthetic tasting in basic techniques of music, downward melody usually has deep sadness, and the composers often use downward melody to express sorrow or sigh. To express work's tragedy spirit, Shostakovich used not only downward melody, and the melody line was very long, the lamentation was especially deep, some even reached an octave (see Figure 1), and the text closely integrated with downward melody lines which foiled the works' tragic further.

Adagio

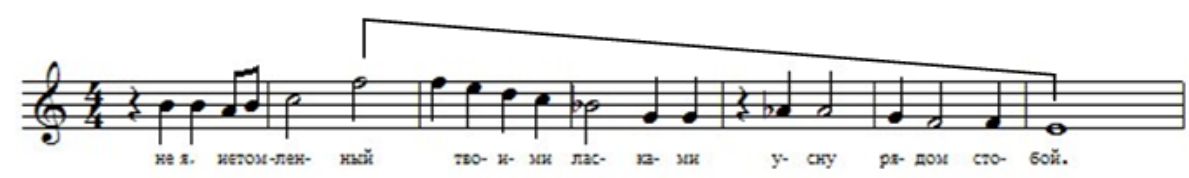

Figure 1.

Andante

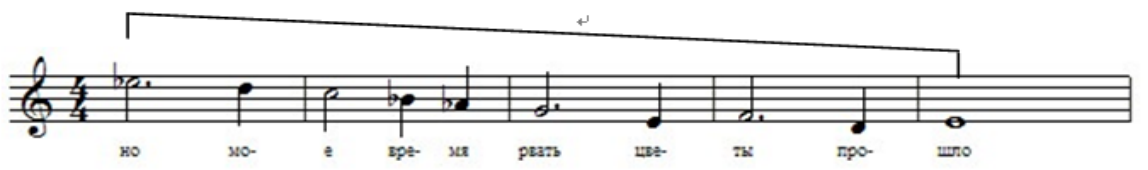

Figure 2.

\subsection{Extremely Slow Repeat of Unison}

Largo

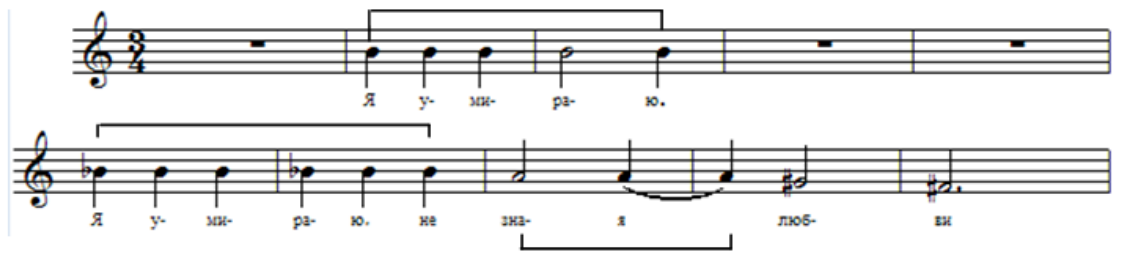

Figure 3.

The song means in Figure 3 "I'm going to die. I was dying; there will be no fanaticism of love". The composer used extremely slow repetition of unison to imitate muttering when hopelessness. The repetition of unison itself has meaning of machinery and numbness, and the rhythm of Largo adds an ill-defines sadness to the machinery and numbness, thus the tragedy figure of a dying protagonist because of love betrayed standard vividly jumped up to paper.

\subsection{The Overall Control of the Speed}

Shostakovich favoured low speed in the vocal music cycle, taking "Six Folk Songs" as an example, except the third one "The Unbridled Glimpse" used Allegretto to adapt to the relatively brisk lyrics content, the remaining five respectively used speed of Andante, Adagio and Largo (see Table 1). Slow speed brought the tone of sadness to works, thus the tragic sense could be clearly shown. 
Table 1.

\begin{tabular}{lll}
\hline Number & Song & Speed \\
\hline 1 & Любовь (Love) & Adante \\
2 & Перед самоубийством (Before Suicide) & Adagio \\
3 & Нескромный взгляд (Wild Glance) & Allegretto \\
4 & В первый и последний раз (The First and the Last Time) & Andante \\
5 & Безнадежная любовь (Hopeless Love) & Adagio \\
6 & Смерть (Death) & Largo \\
\hline
\end{tabular}

\subsection{The Overall Control of the Strength}

The "sorrow" of the vocal cycle is also reflected in the control of strength. Still taking "Six Japanese Poems" as an example, except for the rare paragraphs in rare works, the composers can be recognized to have used strength F because of the need of expressing "scream" and "desperateness", almost the whole vocal music cycle is controlled by strength P. Such layout makes the atmosphere of "sorrow" from the page.

Table 2 .

\begin{tabular}{lll}
\hline Number & Song & Strength \\
\hline 1 & Любовь (Love) & p-pp-p-pp-p \\
2 & Перед самоубийством (Before Suicide) & mf-f-ff-p-pp-f-ff \\
3 & Нескромный взгляд (Wild Glance) & p \\
4 & В первый и последний раз (The First and the Last Time) & p-pp-p-pp-p \\
5 & Безнадежная любовь (Hopeless Love) & p-ppp-p \\
6 & Смерть (Death) & $\mathrm{p}$ \\
\hline
\end{tabular}

\section{Conclusion}

The tragedy spirit, as a tragic aesthetics, is an important topic in the west and is expressed by artists and artistic works together. The tragic spirit of Shostakovich's vocal music cycle not only embodied in the creation tradition of Russian artist and composers tragedy in life of their own, but also in each specific tragedy figure in the works. Death, pessimistic love, the suffering of life are all representation of tragedy spirit of Shostakovich vocal music cycle, and the composer's consummate technique provides strong technical support for conveying this tragic spirit.

\section{Acknowledgements}

This paper has been sponsored by Central Colleges and Universities Basic Research Fund Key Project New International Progress of Music Aesthetics Since the New Century (SN: SWU 1309120).

\section{References}

Aristotle. (1981). Poetics (p. 19). Leo Golden, commentary by O. B. Hardison, Jr.. Tallahassee. FL: Florida State University Press.

Berdyaev. (1995). The Russian Thought: Major Issues of the Nineteenth Century and Early Twentieth Century Russia (p. 2). Lei Yongsheng. Beijing: Three Union Bookstore,

Berlin, I. (2010). The Soul of the Soviet Union: The Russian Culture of the Communist Times (pp. 120-121). Pan Yongqiang and Liu Beicheng. Nanjing: Translation Woods Press.

Berlin, I. (2010). The Soul of the Soviet Union: The Russian Culture of the Communist Times (p. 15). Pan Yongqiang and Liu Beicheng. Nanjing: Translation Woods Press.

Cheng, Z. X., \& Fu, Z. M. (1992). The Historical Resources and Modern Progress of the Western Tragic Aesthetics. Foreign Literatures, $1,4$.

Chernychevsky. (1958). The Aesthetic Relations between Art and Reality. Selected Works of Chernychevsky (Vol. 1, p. 28). Zhou Yang et al. Beijing: Three Union Bookstore.

Engels. (1966). Engels to Fi Laserl. Selected Works of Marx and Engels (Vol. 4, p. 318). Into Chinese and ed. 
Central Translation Bureau, China. People's Press.

Mi, G. H. (2008). On the Tragic Spirit in Shostakovich's Music-With Shostakovich's Symphony as the Illustration (p. 28). Northeast Normal University.

Rung. (1987). Psychology and Literature (p. 141). Feng Chuan. Beijing: Three Union Bookstore.

Shostakovich, S. V. (Ed.). (1981). Testimony: The Memoirs of Dmitri Shostakovich (pp. 172-174). Ye Qiongfang. Beijing: Foreign Language Publishing Bureau.

Yang, X., \& G, L. (2010). Aesthetic Theory (p. 248). Beijing: Beijing University Press.

\section{Copyrights}

Copyright for this article is retained by the author(s), with first publication rights granted to the journal.

This is an open-access article distributed under the terms and conditions of the Creative Commons Attribution license (http://creativecommons.org/licenses/by/3.0/). 